\title{
Activation of Metabotropic Glutamate Receptors Inhibits Calcium Currents and GABA-mediated Synaptic Potentials in Striatal Neurons
}

\author{
Alessandro Stefani, ${ }^{1}$ Antonio Pisani, ${ }^{1}$ Nicola B. Mercuri, ${ }^{1}$ Giorgio Bernardi,, ${ }^{1,2}$ and Paolo Calabresi' \\ ${ }^{1}$ Clinica Neurologica, Dipartimento Sanitá Pubblica, Universitá di Roma Tor Vergata, 00173 Rome, and ${ }^{2} \mid R C C S$, Clinica \\ Santa Lucia, Rome, Italy
}

\begin{abstract}
The transmitter release from GABAergic synapses is thought to be calcium $\left(\mathrm{Ca}^{2+}\right)$ dependent. The pharmacological modulation of $\mathrm{Ca}^{2+}$ currents in central GABAergic neurons may strongly affect GABA release from synaptic sites. The source of striatal GABA-containing synapses is intrinsic to the striatum and mainly originates from axon collaterals of projecting medium-spiny neurons. In order to characterize the role of metabotropic glutamate receptors (mGluRs) in the modulation of central GABA release, we have combined the study of high-voltage-activated (HVA) $\mathrm{Ca}^{2+}$ currents in isolated striatal neurons with the analysis of GABA-mediated synaptic potentials evoked by local stimulation in striatal slices. The mGluR agonists $t-A C P D$ and 1S,3R-ACPD produced a reversible and dose-dependent decrease of both $\mathrm{HVA} \mathrm{Ca}^{2+}$ currents and GABA-mediated synaptic potentials. The mGluR-mediated inhibition of GABA-mediated synaptic potentials was not coupled with changes of the membrane responses to exogenously applied GABA, suggesting an effect on the transmitter release rather than on the GABA receptor sensitivity. The reduction of $\mathrm{Ca}^{2+}$ currents persisted in nifedipine, but not in $\omega$-conotoxin, supporting the involvement of an $\mathrm{N}$-type $\mathrm{Ca}^{2+}$ channel in this pharmacological effect. The GABA-mediated synaptic potentials were greatly reduced by $\omega$-conotoxin. The inhibitory action of $1 S, 3 R$-ACPD on residual GABA-mediated potentials was fully occluded in the presence of $\omega$-conotoxin. In neurons dialyzed with GTP- $\gamma-S$, the reduction of HVA currents was irreversible, suggesting an involvement of a G-protein-mediated mechanism. Preincubation in staurosporine blocked neither the reduction of $\mathrm{Ca}^{2+}$ currents nor the inhibition of synaptic potentials induced by mGluR activation, suggesting that staurosporine-sensitive kinases are not involved in these actions. L-AP3, a noncompetitive antagonist of mGluR-mediated alteration of phosphoinositide (PI) hydrolysis, failed to block both the mGluR-mediated reduction of $\mathrm{Ca}^{2+}$ current and the inhibition of GABA-mediated synaptic potentials. We conclude that activation of mGluRs depresses intrastriatal GABAergic transmission and $\mathrm{Ca}^{2+}$ currents recorded from $\mathrm{pu}-$ tative GABAergic striatal cells. We suggest that a reduction
\end{abstract}

\footnotetext{
Received Sept. 8, 1994; revised Apr. 20, 1994; accepted May 5, 1994.

We thank Giuseppe Gattoni and Massimo Tolu for their excellent technical assistance. This study was supported by CNR grants to A.S. (CNR grant), G.B. (CNR Chimica Fine II), and P.C. (CNR FATMA Stress).

Correspondence should be addressed to Dr. Paolo Calabresi, Clinica Neurologica-Dip. Sanitá Pubblica, Universitá di Roma Tor Vergata, Via O. Raimondo 8, 00173 Rome, Italy.

Copyright @1994 Society for Neuroscience $0270-6474 / 94 / 146734-10 \$ 05.00 / 0$
}

of $\mathrm{Ca}^{2+}$ influx in the striatal GABAergic terminal may account for the mGluR-mediated inhibition of synaptic GABA release in this structure. The modulation of GABA release by mGluRs may have a profound implication in the physiopathology of basal ganglia activity.

IKey words: calcium channels, GABA-mediated potentials, glutamate metabotropic receptors, synaptic transmission, intracellular recordings, whole-cell recordings]

It is known that a large population ( $>90 \%$ ) of striatal neurons are GABAergic neurons projecting to the pallidum and the substantia nigra (DiFiglia ct al., 1976; Kitai ct al., 1979; Wilson and Groves, 1980; Somogyi et al., 1981; Chang et al., 1982). The dendrites of these neurons are covered by a large number of spines, and are therefore referred to as medium-spiny neurons. The spiny projection neurons have local axon collaterals terminating on neighboring spiny cells (Kitai et al., 1979; Wilson and Groves, 1980; Somogyi et al., 1981). The GABAergic local axon collaterals form an inhibitory feedback circuit within the striatum. As a consequence of this synaptic organization, the intrastriatal GABA release can be affected strongly by changes of the electrical activity of the GABAergic spiny neurons. At present, however, it is not well understood how the activation of different transmitter receptors on the somatic region and/or the axon terminals of medium-spiny cells may ultimately influence intrastriatal GABA release.

In several brain areas inhibition of $\mathrm{Ca}^{2+}$ currents has been an attractive hypothesis for the mechanism of inhibition of release by neurotransmitters. Since changes of $\mathrm{Ca}^{2+}$ influx at the axon terminals are difficult to study by electrophysiological techniques, the modulation of somatic $\mathrm{Ca}^{2+}$ currents has been assumed as a possible correlate of the transmitter release. Yet, this extrapolation, in the absence of a concomitant analysis of the synaptic activity, may generate misleading information. For this reason, we have approached the analysis of the pharmacological modulation of intrastriatal GABA release by combining recordings of $\mathrm{Ca}^{2+}$ currents from dissociated striatal neurons with intracellular measurements of GABA-mediated synaptic potentials from striatal slices. In particular, the aim of the present study was to characterize the possible inhibitory effects of mGluRs agonists on GABA-mediated synaptic potentials and on voltage-dependent $\mathrm{Ca}^{2+}$ currents recorded from putative spiny neurons. In hippocampal and cortical neurons, activation of mGluRs causes both depression of excitatory synaptic transmission (Baskys and Malenka, 1991; Desai and Conn, 1991; Desai et al., 1992) and reduction of $\mathrm{HVA} \mathrm{Ca}^{2+}$ currents (Lester and Jahr, 1990; Sayer et al., 1992; Swartz and Bean, 1992; 

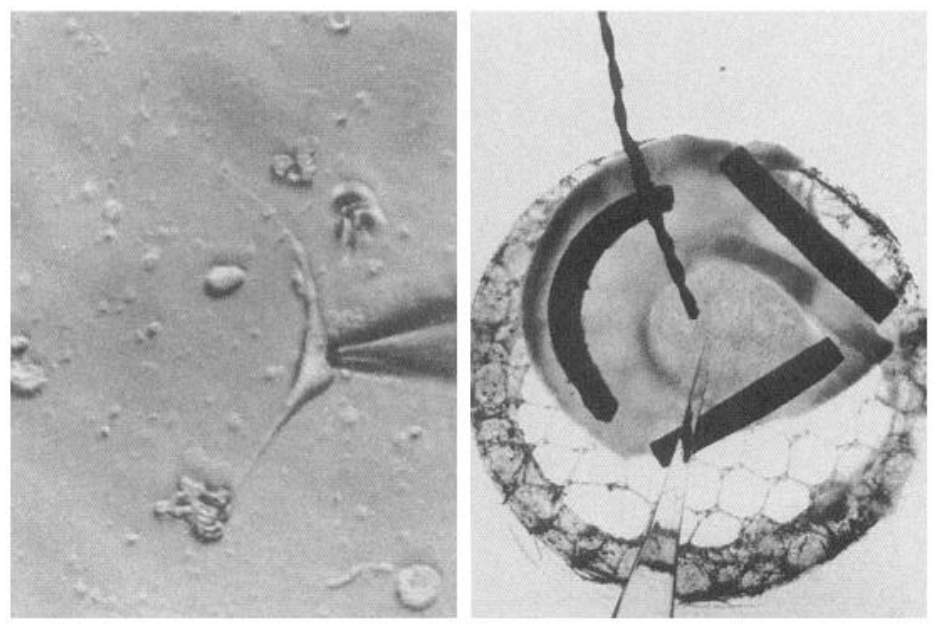
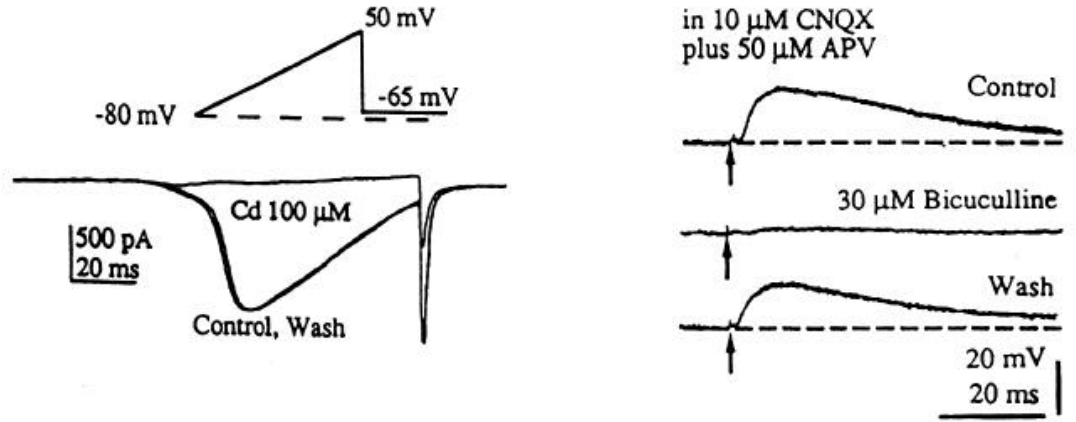

Figure 1. High-voltage-activated $\mathrm{Ca}^{2+}$ currents in isolated striatal neurons and GABA-mediated synaptic potentials evoked in striatal slices. Top, Photomicrographs of a freshly isolated striatal cell (left; magnification, $400 \times$ ) and of a striatal slice (right). Bottom: Left, Ramp-activated (1 msec/1 mV) wholecell $\mathrm{Ba}^{2+}$ currents (traces show current before, during, and after $100 \mu \mathrm{M} \mathrm{CdCl}_{2}$ ). Right, Depolarizing postsynaptic potentials evoked by intrastriatal stimulation in the presence of $10 \mu \mathrm{M}$ CNQX and $50 \mu \mathrm{M}$ APV. Note that bicuculline $(30 \mu \mathrm{M})$ fully abolished the synaptic potential showing that it is mediated by endogenous GABA.
Trombley and Westbrook, 1992; Sahara and Westbrook, 1993). However, the physiological and pharmacological characteristics of these actions are not homogeneous, and the functional relationship between the reduction of the somatic $\mathrm{Ca}^{2+}$ currents and the decrease of synaptic potentials is still unclear.

We have previously reported that activation of striatal mGluRs is involved in both short-term (Calabresi et al., 1992a) and longterm (Calabresi et al., 1992b) depression of excitatory synaptic transmission. These effects have different sensitivity to L-AP3 (Calabresi et al., 1993a) and to chronic lithium treatment (Calabresi et al., 1993b). These findings support the hypothesis of a functional heterogeneity of mGluRs as suggested by recent molecular studies (Nakanishi, 1992). Here we investigate the cellular mechanism underlying the depression of striatal GABAergic transmission caused by the activation of mGluRs; this modulation may influence the physiology of the basal ganglia and the motor behavior.

\section{Materials and Methods}

Slice preparation and intracellular recordings. Male Wistar rats (weighing 150-250 gm) were used. Rats were anesthetized with ether and killed by a heavy blow to the chest that severed major blood vessels. Coronal slices $(200-300 \mu \mathrm{m})$ were prepared from tissue blocks of the brain with the use of a vibratome. These coronal slices included neostriatum, cortex, and corpus callosum (Fig. 1). A single slice was transferred to a recording chamber $(0.5 \mathrm{ml} \mathrm{vol})$ and submerged in a continuously flowing Krebs solution $\left(36^{\circ} \mathrm{C}, 2-3 \mathrm{ml} / \mathrm{min}\right)$ gassed with $95 \% \mathrm{O}_{2}, 5 \% \mathrm{CO}_{2}$. The composition of the solution was (in mM) $126 \mathrm{NaCl}, 2-5 \mathrm{KCl}, 1-2 \mathrm{MgCl}_{2}$, 1-2 $\mathrm{NaH}_{2} \mathrm{PO}_{4}, 2.4 \mathrm{CaCl}_{2}, 11$ glucose, and $25 \mathrm{NaHCO}_{3}$.
Intracellular recording electrodes were filled with either $2 \mathrm{M} \mathrm{KCl}$ or $2 \mathrm{M} \mathrm{K}$-acetate (30-60 M $\Omega$ ). For synaptic stimulation, bipolar electrodes were used. The stimulating electrode was positioned inside striatum, close to the recording electrode ( $\sim 0.5-3 \mathrm{~mm}$ apart). All the experiments concerning the modulation of GABA-mediated potentials by mGluRs were performed in the presence of antagonists of excitatory amino acids receptors (30-50 $\mu_{\mathrm{M}} \mathrm{APV}$ plus $10 \mu \mathrm{M}$ CNQX). Intracellular potentials were recorded with an Axoclamp-2A amplifier, displayed on an oscilloscope, and stored on a digital system. The statistical significance of the experiments was evaluated with the use of Student's $t$ test. Drugs were applied by dissolving them to the desired final concentration in the saline and by switching the perfusion from control saline to drugcontaining saline.

Preparation of isolated cells and whole-cell recordings. Striatal neurons were dissociated from 50 male Wistar rats aged 1-4 months. Striatum was dissected under stereomicroscope from coronal slices $450 \mu$ m thick. Slices were then incubated in a HEPES-buffered Hank's balanced salt solution (HBSS), bubbled with $100 \% \mathrm{O}_{2}$ and warmed at $34^{\circ} \mathrm{C}$. From 30 to $60 \mathrm{~min}$ later, one slice was transferred in HBSS medium supplemented with $1.5 \mathrm{mg} / \mathrm{ml}$ protease XIV (Sigma; see Mody et al., 1989). After 35-45 min of enzymatic treatment, the tissue was repeatedly rinsed in HBSS and mechanically triturated. The cell suspension was finally placed in a Petri dish mounted on the stage of an inverted microscope (Nikon). Cells were allowed to settle for 10-12 min. Neurons were chosen for recordings if presumed to be medium-spiny neurons by their morphology and size (usually bipolar, $15 \mu \mathrm{m}$ major axis) (Fig. 1).

Whole-cell recordings were performed using pipettes (Corning 7052) pulled at a Flaming-Brown and fire polished just prior to use. Pipette resistance ranged from 3 to $8 \mathrm{M} \Omega$ when filled by the internal solution consisting of (in mM) $N$-methyl-D-glucamine, 160; HEPES, 40; EGTA, $10 ; \mathrm{Mg}, 4$; phosphocreatine, 20; ATP, 2-4; GTP, $0-0.2$; leupeptin, 0.2 ; $\mathrm{pH}$ was adjusted to 7.3 with phosphoric acid, and the osmolarity was 265-275 mOsm/liter. After obtaining the whole-cell configuration, the cells were usually bathed in a medium composed of (in $\mathrm{mm}$ ) $\mathrm{NaCl}, 135$ 
A

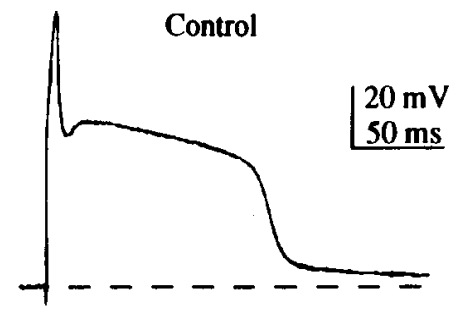

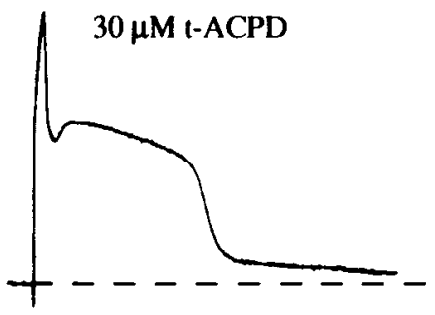

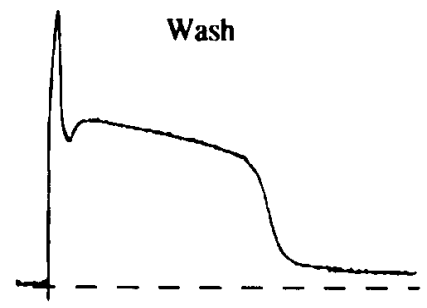

B

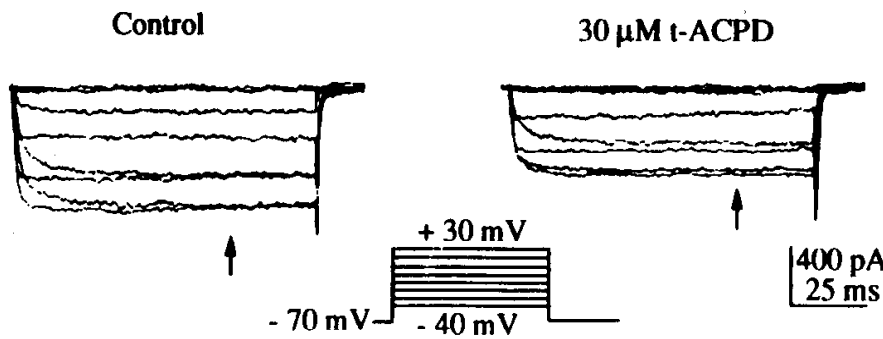

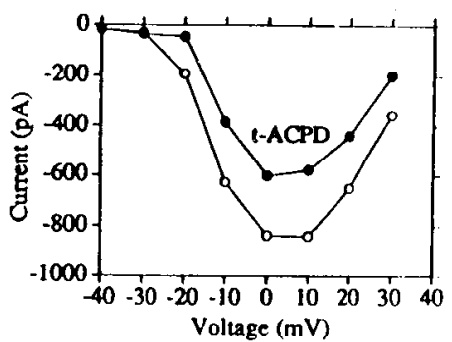

Figure 2. $t$-ACPD reduces $\mathrm{Ca}^{2+}$-mediated plateau potentials as well as $\mathrm{HVA}$ currents. $A$, In a striatal neuron intracellularly recorded with a $\mathrm{CsCl}$ $(2 \mathrm{M}$ )-filled electrode (plus $10 \mathrm{mM}$ external TEA), depolarizing steps ( $5 \mathrm{msec}$ duration, $1 \mathrm{nA}$ intensity) activated plateau potentials; $30 \mu \mathrm{M} t$-ACPD reduced the duration of the plateau potential (middle trace); the effect fully recovered after the interruption of the drug application (right trace). $B$, HVA Ca ${ }^{2+}$ currents were activated by voltage steps from -50 to $+30 \mathrm{mV}$ under control condition (left traces, holding potential $-70 \mathrm{mV}$ ); $30 \mu \mathrm{M}$ t-ACPD reduced HVA currents (middle traces; the inhibition at $-10 \mathrm{mV}$ was about $20 \%$ ). Right, I/V plot of peak currents in control condition (open circles) and in the presence of the mGluR agonist (solid circles).

$140 ; \mathrm{BaCl}_{2}, 5 ; \mathrm{CsCl}_{2}, 5 ; \mathrm{HEPES}, 10 ; \mathrm{TTX}, 0.001 ; \mathrm{pH}$ was adjusted to 7.4 with $\mathrm{NaOH}$ and the osmolarity to $300-305 \mathrm{mOsm} /$ liter with glucose. In a subset of recordings $(n=20), 150 \mathrm{mM}$ TEA was substituted for $\mathrm{Na}$. Control as well as drug solutions were applied with a linear array of six gravity-fed capillaries positioned within $500 \mu \mathrm{m}$ of the patched neuron. Recordings were made with an Axopatch 1D at room temperature $\left(21-22^{\circ} \mathrm{C}\right)$. Series resistance compensation $(70-80 \%)$ was employed. Data were low-pass filtered (corner frequency $=5 \mathrm{kHz}$ ). For data acquisition and analysis, pCLAMP 5.51 running on a PC486 computer was used. $\mathrm{Ba}^{2+}$ currents were studied with voltage steps and ramps. Ramp speed $(0.8-1 \mathrm{mV} / \mathrm{msec})$ was chosen to maximize the agreement with the current-voltage relationship obtained with this method and that derived from short $(30 \mathrm{msec})$ stcp depolarizations.

Drugs. Aminophosphonovalerate (APV), bicuculline, GABA, guanosine-5'-triphosphate (GTP), guanosine-5' $-\gamma$-triphosphate (GTP- $\gamma-S)$, nifedipine, pronase E, staurosporine, tetrodotoxin (TTX), and tetraethylammonium (TEA) were obtained from Sigma (St. Louis, MO). $\omega$-Conotoxin was obtained from Sigma and from Bachem (Bubendorf, $\mathrm{CH})$. 6-Cyano-7-nitroquinoxaline-2,3-dione (CNQX), trans-( \pm -1-1-amino-1,3-cyclopentanedicarboxylic acid ( $t$-ACPD), $1 S, 3 R$-1-aminocyclopentane-1,3-dicarboxylic acid ( $S, 3 R$-ACPD), and L-2-amino-3-phosphonopropionic acid (L-AP3) were obtained from Tocris Neuramin (Bristol, UK). Bay K 8644 was a gift of Bayer.

\section{Results}

Characterization of $\mathrm{Ca}^{2+}$ currents and of GABA-mediated synaptic potentials

Whole-cell patch-clamp recordings were obtained from 102 acutely dissociated striatal neurons. Recordings were taken from cells with medium-sized cell bodies that previous retrograde labeling and single-cell expression profiling have revealed to be medium-spiny projecting neurons (Surmeier et al., 1992).

As shown in Figure 1, in these cells voltage ramps from -80 $\mathrm{mV}$ to $+50 \mathrm{mV}$ elicited inward barium $\left(\mathrm{Ba}^{2+}\right)$ currents that were blocked by $100 \mu \mathrm{M}$ Cadmium $\left(\mathrm{Cd}^{2+}\right)$, indicating that they could be attributed to permeation through $\mathrm{Ca}^{2+}$ channels.
$\mathrm{Ba}^{2+}$ was used as a charge carrier to minimize current rundown during pharmacological analysis. Previous work in these cells (Bargas et al., 1994) has shown that, in adult medium-sized neurons, currents are predominantly of the HVA type. Lowvoltage-activated (LVA) currents have consistently been observed in cultured striatal cells (Bargas et al., 1991) and in 40\% of isolated neurons from young animals (3-4 weeks; Hoehn et al., 1993). In our cells, obtained from adult rats (1-4 months), LVA currents were only rarely seen ( 7 of 90 neurons), and their small amplitude did not allow further pharmacological characterization. Even by utilizing voltage steps instead of voltage ramps and $\mathrm{Ca}^{2+}$ as a charge carrier instead of $\mathrm{Ba}^{2+}, \mathrm{LVA}$ were only rarely observed (unpublished observations).

Intracellular recordings, obtained from corticostriatal slice preparations, revealed that intrastriatal stimulation evokes depolarizing synaptic potentials (DSPs) that are only partially blocked by glutamate ionotropic receptors antagonists (Calabresi et al., 1991, 1992a; Jiang and North, 1991). In the presence of $10 \mu \mathrm{M}$ CNQX, an AMPA-like glutamate receptor antagonist, plus 30-50 $\mu \mathrm{M} \mathrm{APV}$, an NMDA receptor antagonist, intrastriatal synaptic stimulation evoked a DSP that was reversibly blocked by $30 \mu \mathrm{M}$ bicuculline (Fig. 1). This finding indicates that endogenous GABA, acting on bicuculline-sensitive $\mathrm{GABA}_{\mathrm{A}}$ receptors, mediates part of the intrastriatal synaptic transmission. Even with electrodes that contained potassium acetate, the GABA-mediated synaptic potentials were depolarizing at the resting membrane potential $(-85 \perp 3 \mathrm{mV}, n=25)$. The GABAmediated DSPs were reduced in amplitude by depolarization and reversed in polarity at $-55 \pm 4 \mathrm{mV}(n=5)$ when recorded with potassium acetate electrodes. In cells recorded with potassium chloride-filled electrodes, the extrapolated reversal potential was $-31 \pm 2 \mathrm{mV}(n=5)$. 
Effects of $m G$ GluRs agonists on $\mathrm{Ca}^{2+}$-mediated plateau

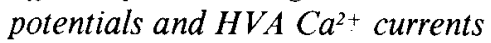

Intracellular recordings obtained from striatal neurons in brain slice preparations by utilizing cesium chloride $(2 \mathbf{M})$-filled electrodes showed that, in the presence of $10 \mathrm{~mm}$ external TEA, brief (5-20 msec) depolarizing pulses produced $\mathrm{Ca}^{2+}$-mediated plateau potentials (Misgeld et al., 1986; Calabresi et al., 1987). Bath application of $t$-ACPD (3-100 $\mu \mathrm{M})$ produced a reversible decrease of the duration of these plateau potentials. In most of the cases (seven of ninc), this effect was not coupled with significant changes of their membrane potential (Fig. 2); in two cells, the depression of the plateau potential was coupled with a slight membrane depolarization ( 5 and $4 \mathrm{mV}$, respectively; data not shown).

In acutely dissociated striatal cells, $\mathrm{Ca}^{2+}$ currents were isolated by blocking voltage-dependent sodium channels with TTX and by virtually eliminating potassium currents (see Materials and Methods). As shown in Figure 2, from an holding potential of $-70 \mathrm{mV}, 100 \mathrm{msec}$ depolarizing steps of progressively increasing amplitude (from -50 up to $+30 \mathrm{mV}$ ) evoked sustained inward $\mathrm{Ba}^{2+}$ currents through $\mathrm{HVA} \mathrm{Ca}{ }^{2+}$ channels. The current showed little inactivation even with $400 \mathrm{msec}$ voltage jumps (data not shown). The inward current activated above $-40 \mathrm{mV}$, peaked at $0 \mathrm{mV}$, and then declined (see $I / V$ plot in Fig. 2). Rapid perfusion with $t$-ACPD (3-300 $\mu \mathrm{M})$ reversibly decreased this HVA Ca ${ }^{2+}$ current in the large majority of cells (43 of 45). In the presence of $t$-ACPD there was a minimal change in the current time course, and the current-voltage plot showed a nearuniform current suppression at all voltages, suggesting that the activation parameters are not shifted along the voltage axis (plot in Fig. 2). The inhibitory action of $t$-ACPD on $\mathrm{Ca}^{2+}$ currents was also evident when studied utilizing voltage ramps (Fig. 3). The $t$-ACPD-mediated inhibition of the $\mathrm{HVA} \mathrm{Ca}^{2+}$ current was dose dependent; the minimal effective concentration was $3 \mu \mathrm{M}$, whereas the effect was maximal at $100 \mu \mathrm{M}$ (Fig. 3). The inhibitory action of $t$-ACPD on HVA currents was mimicked by the active isomer 1S,3R-ACPD, which showed a dose-dependent curve similar to that observed for $t$-ACPD (data not shown). In 15 neurons, we used $2.4 \mathrm{~mm}$ external $\mathrm{Ca}^{2+}$ instead of $\mathrm{Ba}^{2+}$ as the charge carrier for HVA currents; dose-response curves for both agonists were similar to those observed when $5 \mathrm{~mm} \mathrm{Ba}^{2+}$ were utilized (data not shown). In particular, also in the presence of $\mathrm{Ca}^{2+}$ a maximal inhibition was obtained with $100 \mu \mathrm{M} t$-ACPD $(-36.2 \pm 3 \%, n=4)$.

\section{Effect of $m G$ GuRs agonists on GABA-mediated synaptic potentials}

As shown in Figure 3, $t$-ACPD induced a dose-dependent decrease of the GABA-mediated synaptic potential evoked in striatal slices by intrastriatal stimulation. In most of the cases this effect was not coupled with significant changes of membrane potential and input resistance of the recorded neurons (18 of $22)$. In the remaining cells, a slight (3-5 $\mathrm{mV})$ membrane depolarization was observed during the application of $t$-ACPD (data not shown). The minimal concentration required to obtain significant inhibition of GABA-mediated DSPs was $3 \mu \mathrm{M}$, whereas $100 \mu \mathrm{M}$ was the dose producing maximal inhibition of the synaptic potentials (Fig. 3). As well as for the inhibition of HVA $\mathrm{Ca}^{2+}$ currents, also the $t$-ACPD-mediated depression of DSPs was mimicked by $1 S, 3 R-A C P D(n=9)$. Also in this case, the dose-response curve was similar to that obtained for $t$-ACPD.
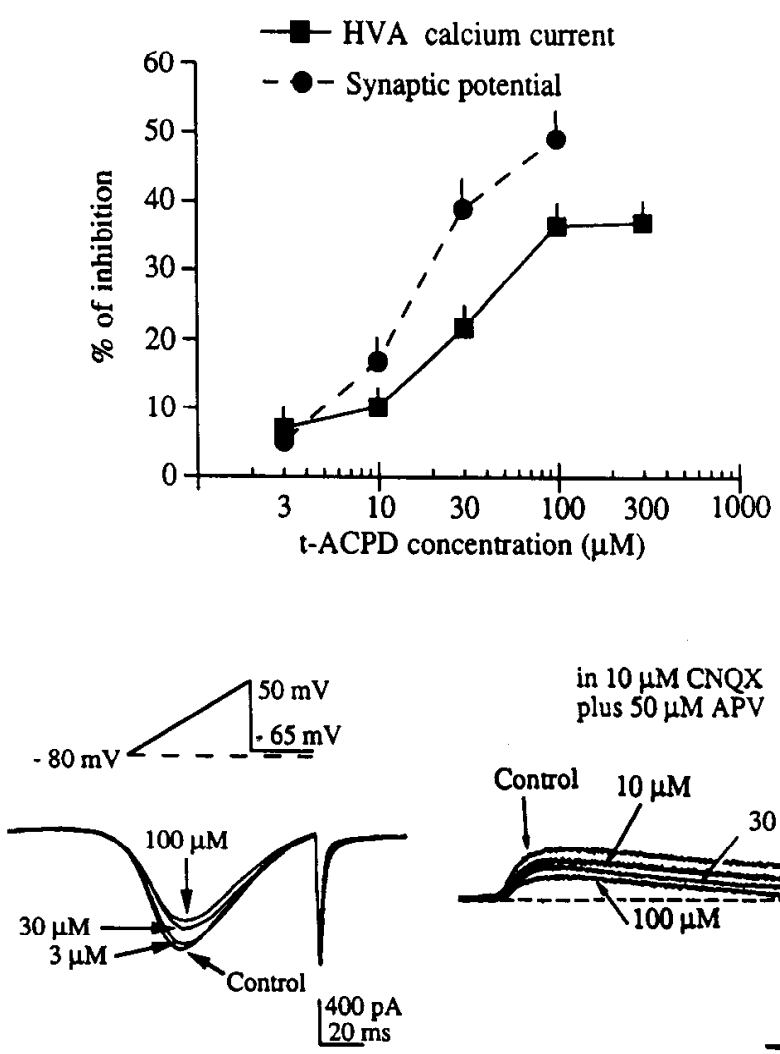

in $10 \mu \mathrm{M} \mathrm{CNQX}$ plus $50 \mu \mathrm{M}$ APV

Figure 3. Dose-response curves of mGluR-mediated effects on $\mathrm{Ca}^{2+}$ currents and GABA-mediated synaptic potentials. Top, Percentage of inhibition of HVA $\mathrm{Ca}^{2+}$ currents and of GABA-mediated synaptic potentials by different concentrations of $t$-ACPD. Each point represents the mean of at least four experiments. Bottom, Representative dosedependent modulation by the mGluR agonist on ramp-activated wholecell $\mathrm{Ba}^{2+}$ currents (left) and GABA-mediated postsynaptic potentials (right).

In order to study whether the ACPD-mediated depression of the DSPs was caused by changes of $\mathrm{GABA}_{\mathrm{A}}$ receptor sensitivity, we characterized the membrane responses of striatal neurons to the application of exogenous GABA before and during the application of $t$-ACPD. As shown in Figure 4, activation of mGluRs by $t$-ACPD or by $1 S, 3 R$-ACPD (10-100 $\mu \mathrm{M})$ affected neither membrane depolarization $(n=6)$ nor inward current $(n=6)$ caused by brief applications of exogenous GABA $(300 \mu \mathrm{M})$. In fact, in control condition the GABA-induced membranc dcpolarization and inward current were, respectively, $16 \pm 5 \mathrm{mV}$ $(n=6)$ and $+320 \pm 80 \mathrm{pA}(n=6)$. In ACPD, the GABAinduced depolarization and inward current were, respectively, $17 \pm 5 \mathrm{mV}(n=6)$ and $305 \pm 95 \mathrm{pA}(n=6)$. These differences were not statistically significant, suggesting that the postsynaptic sensitivity of $\mathrm{GABA}_{\mathrm{A}}$ receptor is not significantly altered by mGluR activation.

\section{Type of $\mathrm{HVA} \mathrm{Ca}^{2+}$ channels inhibited by the activation of $m G l u R s$}

Striatal neurons have multiple types of $\mathrm{HVA} \mathrm{Ca}^{2+}$ channels (Bargas et al., 1991, 1994; Hoehn et al., 1993). At present, the best distinction of these subtypes of these $\mathrm{Ca}^{2+}$ channels is obtained by utilizing a pharmacological approach. For this reason, we have utilized the dihydropyridine (DHP) agonist Bay K 8644 , which is known to promote long-lasting $\mathrm{Ca}^{2+}$ tail current in central neurons (Nowicky et al., 1985). Also in striatal cells, Bay 
Control

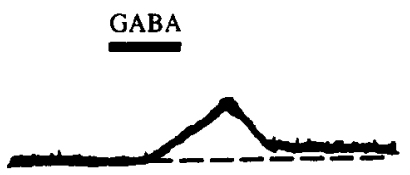

a

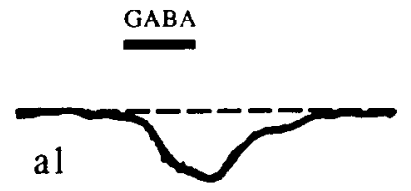

$30 \mu \mathrm{M}$ 1S,3R-ACPD

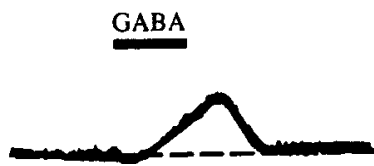

b

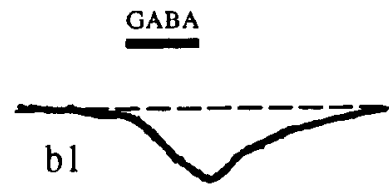

Wash
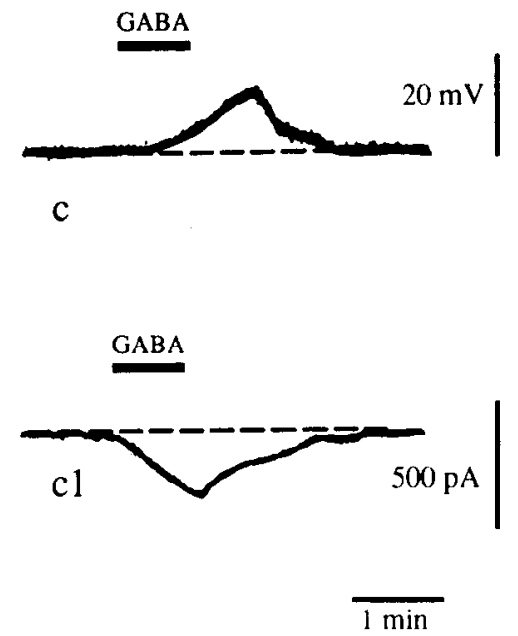

Figure 4. The mGluRs agonists do not modify the postsynaptic responses to exogenously applied GABA in striatal slice: current-clamp (top) and voltage-clamp (bottom) recordings of neuronal responses to GABA application. $a / a 1$, Responses in control condition. $b / b 1$, Responses in the presence of $30 \mu \mathrm{M} 1 S, 3 R-A C P D$. $c / c 1$, Wash. Neither GABA-mediated depolarization nor GABA-mediated inward current was significantly affected by the mGluR agonist.

$\mathrm{K} 8644(2 \mu \mathrm{M})$ enhanced both HVA Ca ${ }^{2+}$ current and $\mathrm{Ca}^{2+}$ tails (Fig. $5 A$ ). In the presence of Bay $\mathrm{K} 8644, t$-ACPD was still effective in producing inhibition of HVA currents $(n=5)$. However, the activation of mGluRs did not alter the $\mathrm{Ca}^{2+}$ tails recorded in the presence of the DHP agonist (Fig. $5 B ; n=5$ ), suggesting that L-type Ca channels are not strongly involved in the mGluR-induced modulation of $\mathrm{HVA} \mathrm{Ca}^{2+}$ currents. A further evidence against a role of L-type $\mathrm{Ca}^{2+}$ channels in the mGluR-mediated modulation of $\mathrm{HVA} \mathrm{Ca}^{2+}$ currents was obtained from experiments utilizing the DHP antagonist nifedipine $(5 \mu \mathrm{M})$. As shown in Figure $5 \mathrm{C}$, nifedipine produced a significant reduction of HVA currents, yet the $\mathrm{mGluR}$-mediated response was not significantly altered by nifedipine. On the other hand, $\omega$-conotoxin, an N-type Ca-channel antagonist, reduced by itself HVA currents and fully occluded the mGluR-mediated action on these currents (Fig. $5 D$ ). These findings suggested that an $\mathrm{N}$-type, rather than an L-type $\mathrm{Ca}^{2+}$ channel, is involved in the modulatory action of mGluRs.

Effects of $\omega$-conotoxin on the GABA-mediated synaptic potentials and on the inhibitory action of $1 \mathrm{~S}, 3 \mathrm{R}-A C P D$

Since $\omega$-conotoxin was able to occlude the action of mGluR agonists on $\mathrm{Ca}^{2+}$ channels, we also tested the role of $\omega$-conotoxin-sensitive channels in the generation of GABA-mediated synaptic potentials. Bath application of $5 \mu \mathrm{M} \omega$-conotoxin produced a large reduction of GABA-mediated synaptic potentials $(-81 \pm 13 \%, n=5$; see Fig. $6 A a b, B)$. We also tested the inhibitory action of $1 S, 3 R$-ACPD in the presence of $\omega$-conotoxin. For this reason, considering that $\omega$-conotoxin per se, in some cases, almost completely abolished the synaptic potentials, before the application of $1 S, 3 R$-ACPD we usually had to increase the intensity of the synaptic stimulation. Under this condition, $1 S, 3 R$-ACPD (30-100 $\mu \mathrm{M})$ did not cause significant reduction of synaptic potentials $(n=4, p>0.05$; Fig. $6 \mathrm{Acd}, C)$. However, even in this condition, bath application of $30 \mu \mathrm{M}$ bicuculline fully abolished the GABA-mediated synaptic potentials ( $n=3$; Fig. 6Ae).

\section{Coupling between receptor and channel involves $G$-proteins}

We tested the involvement of a G-protein in the coupling between mGluRs and HVA $\mathrm{Ca}^{2+}$ channels in striatal neurons by comparing cell dialyzed with GTP with cells dialyzed by its nonhydrolyzable analog GTP- $\gamma-S$. This approach has previously been utilized in the study of G-protein-mediated pharmacological actions in other central neurons. As earlier shown for hippocampal and cortical cells (Lester and Jahr, 1990; Sayer et al., 1992; Swartz and Bean, 1992), in striatal neurons dialyzed for 6-10 min with $300 \mu \mathrm{M}$ GTP- $\gamma-\mathrm{S}$, the inhibition of HVA $\mathrm{Ca}^{2+}$ currents by mGluR activation was irreversible. In fact, only ACPD applications occurring within 2-5 min from the onset of the intracellular dialysis were fully reversible, while application of mGluR agonists after this period produced irreversible effects on HVA currents $(n=6$, Fig. $7 A)$. In contrast, in neurons dialyzed with $300 \mu \mathrm{M}$ GTP, the suppression of HVA currents by mGluR agonists was readily reversible during all the recording time ( $n=5$, Fig. $7 B$ ). These findings suggest that in striatal neurons, as in other neuronal types, the mGluRmediated modulation of HVA currents involves a G-proteinlinked mechanism.

\section{Lack of effect of staurosporine on mGluR actions on HVA currents and GABA-mediated synaptic potentials}

G-protein-coupled receptors can act via diffusible second messengers (Trautwein et al., 1986; Dunlap et al., 1987) or via the direct interaction with the $\alpha$ subunit of the ion channel (Brown and Birnbaumer, 1988; Lipscombe et al., 1989; Toselli et al., 1989). We examined whether protein kinase activation was required for coupling of mGluRs to $\mathrm{Ca}^{2+}$ channels and for the inhibition of GABA-mediated synaptic transmission by mGluR 

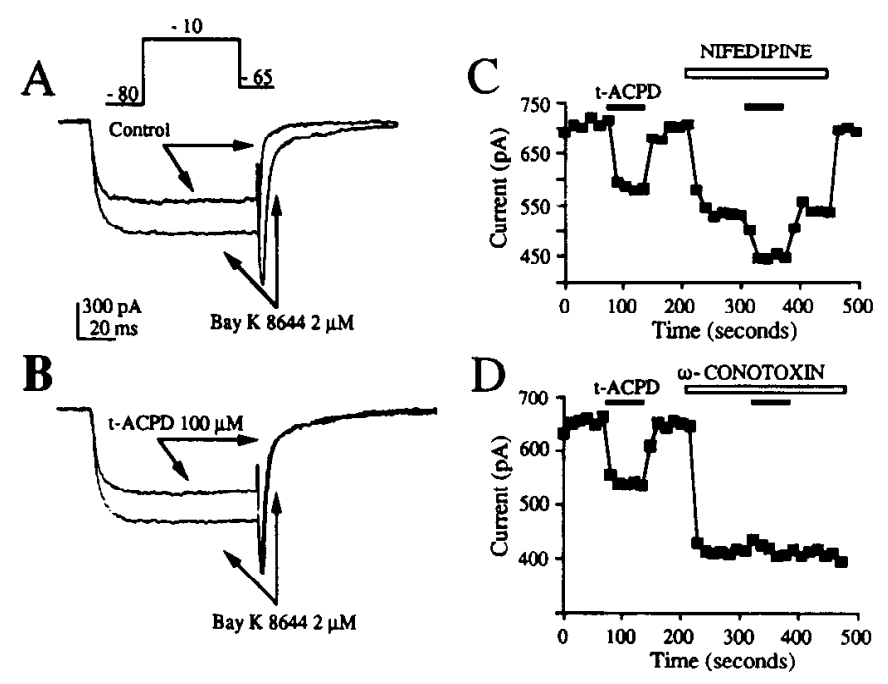

$\mathrm{E}$

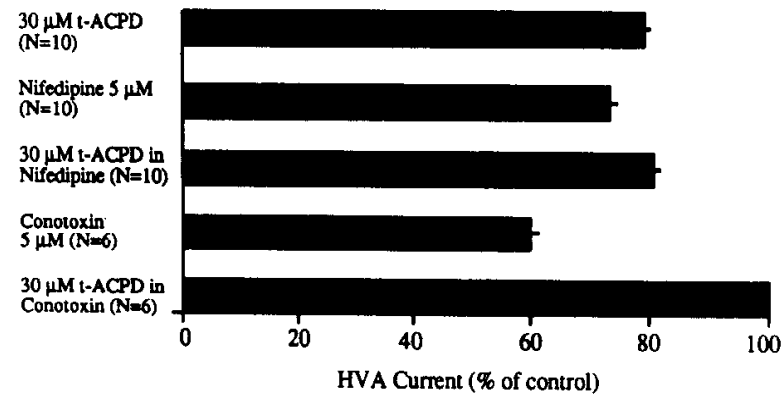

Figure 5. Type of HVA Ca ${ }^{2+}$ channel involved in mGluR-mediated modulation. $A$ and $B$, The slow tail currents enhanced by the DHP agonist Bay $\mathrm{K} 8644$ are not suppressed by $t$-ACPD. $A$, $\mathrm{Ba}^{2+}$ currents evoked by a step pulse from -80 to $-10 \mathrm{mV}$ were increased in the presence of $2 \mu \mathrm{M}$ Bay K 8644; note the long-lasting tail at $-65 \mathrm{mV}$ (arrows). B,t-ACPD at $100 \mu \mathrm{M}$ decreased $\mathrm{Ba}^{2+}$ currents without significantly affecting the Bay K 8644-induced tail (arrows; same finding in other four neurons). $C$ and $D$, Representative responses to mGluR agonist in the presence of $5 \mu \mathrm{M}$ nifedipine and $5 \mu \mathrm{M} \omega$-conotoxin. $C$, Persistence of the $t$-ACPD-mediated modulation in nifedipine (analogous findings in other nine neurons). $D, \omega$-Conotoxin suppressed the $t$-ACPD-mediated modulation (same finding in other five cells). $E$, The histograms summarize the percentage of modulation of striatal HVA $\mathrm{Ca}^{2+}$ currents by different pharmacological agents.

agonists. Therefore, we incubated (for at least $10-15 \mathrm{~min}$ ) both dissociated neurons and striatal slices in a medium containing $50 \mathrm{~nm}$ staurosporine, a kinase inhibitor (Hidaka and Kobayashi, 1992), which at this concentration is able to block striatal LTD (Calabresi, unpublished data). As shown in Figure 8, incubation in staurosporine significantly affected neither mGluR-mediated inhibition of HVA currents $(n=7)$ nor ACPD-mediated depression of GABAergic transmission $(n=10)$, suggesting that staurosporine-sensitive protein kinases are not involved in these effects produced by mGluR activation.

\section{Lack of effect of $L-A P 3$ on mGluR-mediated actions on HVA currents and GABA-mediated synaptic potentials}

L-AP3 has been reported to block noncompetitively the phosphoinositide hydrolysis mediated by the activation of mGluRs (Schoepp et al., 1990) and to alter synaptic plasticity in different
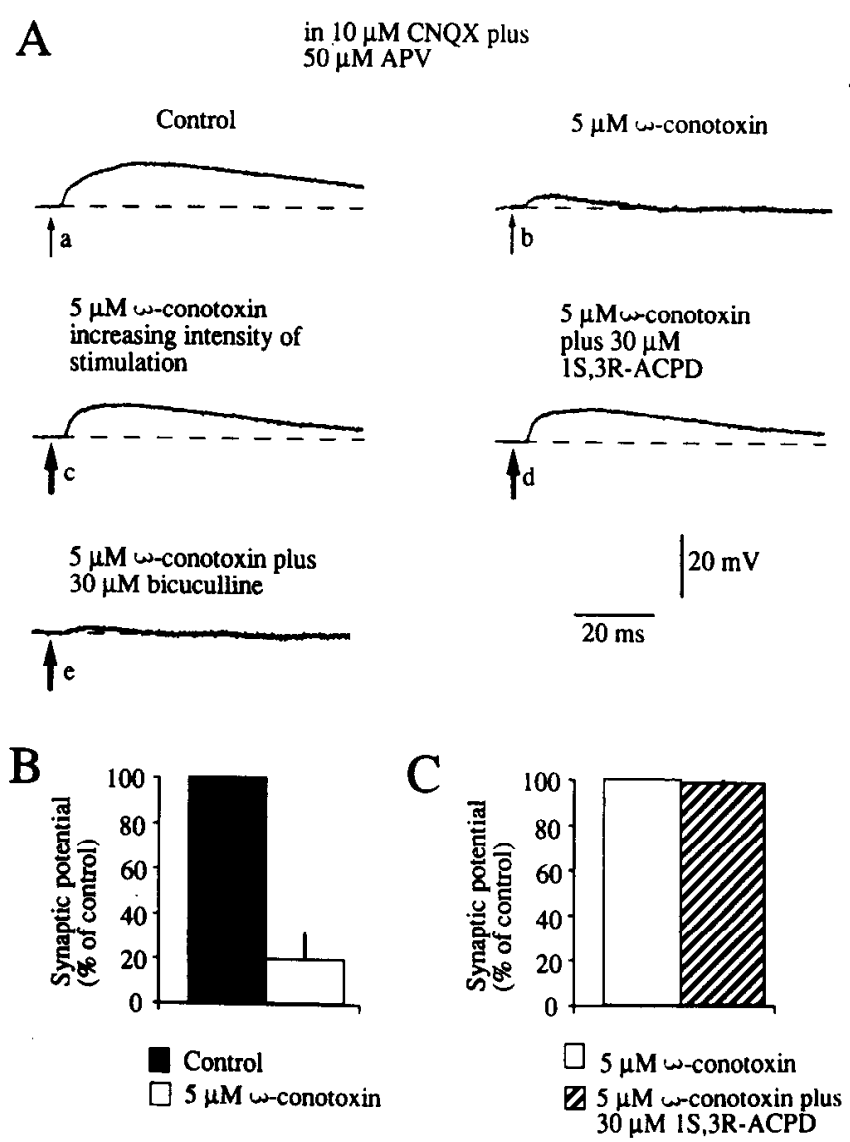

Figure 6. $\omega$-Conotoxin decreases GABA-mediated potentials and occludes the action of $1 S, 3 R$-ACPD. $A$, Depolarizing postsynaptic potential evoked by intrastriatal stimulation in the presence of $10 \mu \mathrm{M}$ CNQX and $50 \mu \mathrm{M}$ APV $(a)$. $\omega$-Conotoxin $(5 \mu \mathrm{M})$ greatly reduced the GABAmediated synaptic potentials $(b)$. In the presence of $\omega$-conotoxin, the stimulus intensity was enhanced to restore a consistent synaptic potential (c). Under this condition, $30 \mu \mathrm{M} 1 S, 3 R$-ACPD was ineffective on the GABA-mediated potentials $(d)$. Bicuculline $(30 \mu \mathrm{M})$ almost abolished the GABA-mediated synaptic potentials in the $\omega$-conotoxin-added bath (e). $B$, The histogram shows the effect of $\omega$-conotoxin in reducing GABA-mediated synaptic potentials $(n=5)$. $C$, The histogram shows that, in the presence of $\omega$-conotoxin, the inhibitory action of $1 S, 3 R$ ACPD is abolished (for details, see text).

brain areas (Stanton et al., 1991; Zheng and Gallagher, 1992; Calabresi et al., 1993a). Yet, this antagonist has becn rcportcd not to be effective in counteracting some electrophysiological effects induced by mGluR agonists in different brain areas (Calabresi et al., 1993a; Schoepp and Conn, 1993). We tested the possibility that L-AP3 might antagonize mGluR-induced inhibition of $\mathrm{HVA} \mathrm{Ca}^{2+}$ currents and of GABA-mediated synaptic potentials in the striatum. As shown in Figure 9, $100 \mu \mathrm{M}$ L-AP3 did not affect the mGluR-induced depression of HVA currents $(n=7)$. However, higher concentrations of L-AP3 $(300-500 \mu \mathrm{M})$ in some cells (two of five) caused a reduction $(-12 \%$ and $-18 \%)$ of HVA currents.

Similarly, the inhibition of GABA-mediated potentials by $t$-ACPD was not blocked by the incubation of the slice in 30 $\mu$ M L-AP3 (Fig. 9; $n=5$ ). L-AP3 (50-100 $\mu$ M) produced by itself a depression of GABA-mediated synaptic transmission $(-15 \pm$ $5 \mathrm{mV}, n=5$ ). Even in this condition, the mGluR agonistmediated inhibition of GABA-mediated potentials was not significantly affected ( $n=4$; data not shown). 

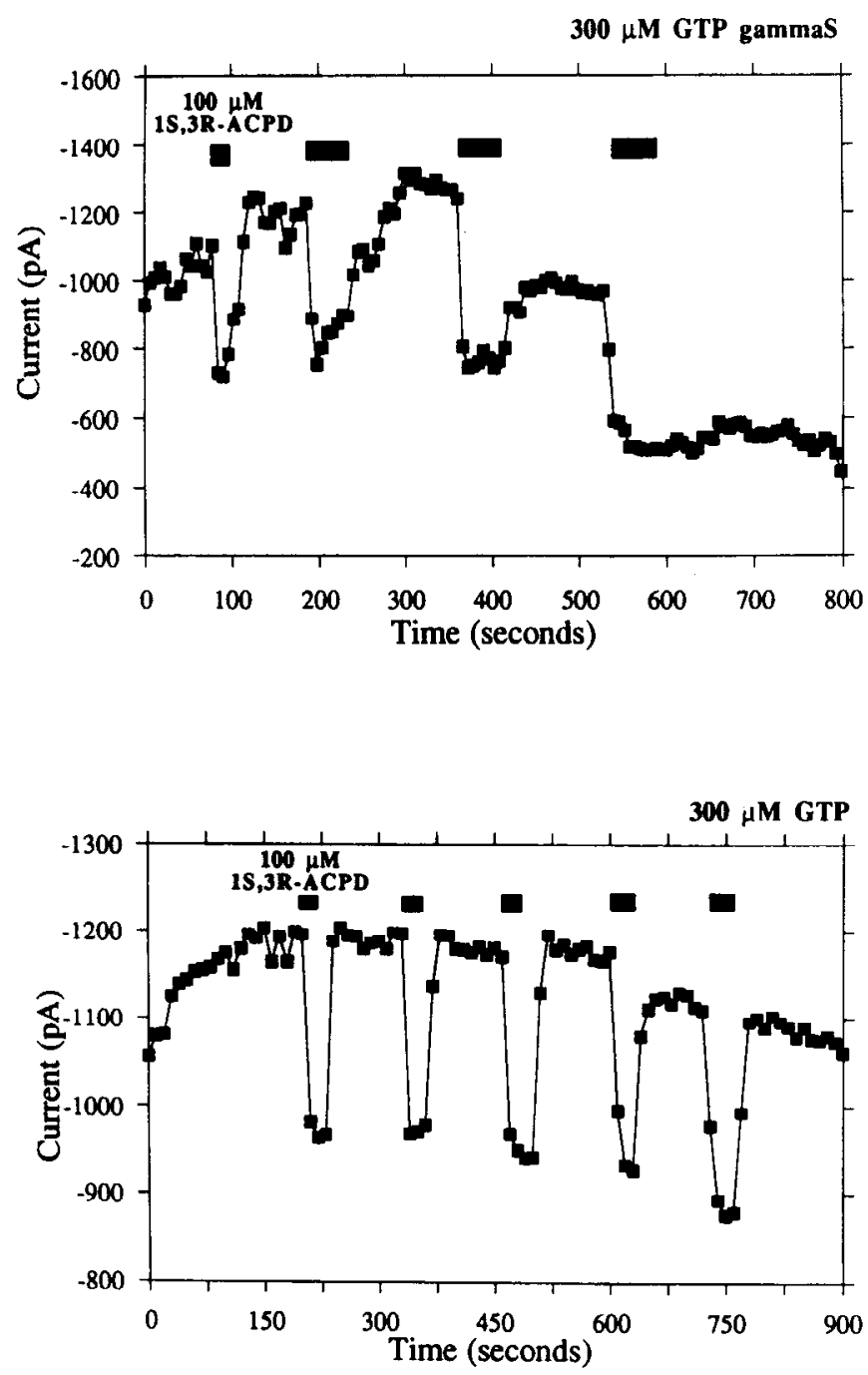

Figure 7. A G-protein couples mGluRs to $\mathrm{Ca}^{2+}$ channels. $A$, In a cell dialyzed with $300 \mu \mathrm{M}$ GTP- $\gamma$-S, only the first two applications of 100 $\mu \mathrm{M} 1 S, 3 R$-ACPD reversed (note the slight run-up of the current); however, after 7-8 min of dialysis, the current modulation was irreversible (analogous finding in other four neurons). $B$, In a cell dialyzed with 300 $\mu \mathrm{M}$ GTP, the modulation of $\mathrm{Ba}^{2+}$ currents by $100 \mu \mathrm{M} 1 S, 3 R$-ACPD was still reversible after five applications.

\section{Discussion}

Heterogeneity of $m G l u R s$

Although the first studies concerning the function of mGluRs in central neurons have shown that activation of these receptors causes excitatory effects (for reviews, see Schoepp et al., 1990; Miller, 1991; Schoepp and Conn, 1993), recent studies have provided evidence in favor of more complex roles of these receptors in the brain. Furthermore, a variety (at least six subtypes) of mGluRs have been cloned recently (for a review, see Nakanishi, 1992). Some of the responses mediated by mGluRs involve intracellular $\mathrm{Ca}^{2+}$ mobilization as a consequence of an altered PI metabolism (Schoepp and Conn, 1993). L-AP3 is an effective antagonist of these responses (Irving et al., 1990). L-AP3sensitive mGluRs have been implicated in the formation of synaptic plasticity in hippocampus (Otani and Ben-Ari, 1991), septum (Zheng and Gallagher, 1992), cerebellum (Linden et al., 1991), and striatum (Calabresi et al., 1992b). A major role of L-AP3-sensitive mGluRs in the generation of long-term changes of synaptic function has been recently provided in the striatum (Calabresi et al., 1993a); lithium treatment, a procedure that is known to alter PI metabolism and intracellular $\mathrm{Ca}^{2+}$ mobilization (Nahorski et al., 1991), blocks the formation of striatal LTD (Calabresi et al., 1993b).

Several other actions mediated by mGluRs activation are not sensitive to L-AP3. Among these, the inhibition of excitatory synaptic transmission (Desai et al., 1992; Glaumm and Miller, 1992; Calabresi et al., 1993a; Lovinger et al., 1993) and the depression of $\mathrm{Ca}^{2+}$ currents (Sayer et al., 1992). The L-AP3insensitive responses have been linked either to a direct interaction between the G-protein and the ion channel or to an inhibitory effect on cAMP cascade (Nakanishi, 1992). Taken together, these findings suggest that the mGluRs that mediate the short- and long-term modulation of synaptic transmission have rather different physiological and pharmacological properties.

\section{Modulation of GABA-mediated synaptic potentials by mGluRs}

Together with the reduction of synaptic transmission mediated by excitatory amino acids, mGluR-mediated reduction of GABAergic synaptic potentials has been described in the striatum (Calabresi et al., 1992a), nucleus tractus solitarius (Glaumm and Miller, 1992), and hippocampus (Desai and Conn, 1991). In the hippocampus, the mGluR-mediated reduction of inhibitory postsynaptic potentials was partially ascribed to concomitant decrease of synaptic excitation of GABAergic interneurons, thus leading to disinhibition. In contrast, we have shown that in the striatum the reduction of GABA-mediated synaptic potentials was observed even in the presence of ionotropic glutamate receptor antagonists, a condition that allows the pharmacological isolation of GABA-mediated synaptic potentials. Furthermore, the inhibition of striatal GABA-mediated synaptic potentials was not coupled with significant changes of the membrane responses to the applications of exogenous GABA; therefore, the sensitivity of GABA receptors located on medium-spiny cells does not seem to be altered by the activation of mGluRs. These findings, taken together, strongly support the hypothesis that mGluR agonists reduce the release of GABA in the striatum.

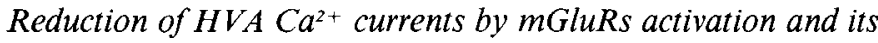
implication for $G A B A$ release

Anatomical and functional data indicate that a significant part of the recurrent GABAergic innervation in the striatum is provided by axon collaterals originating from medium-spiny projecting neurons (DiFiglia et al., 1976; Kitai et al., 1979; Somogyi et al., 1981). In fact, GABAergic aspiny interneurons represent only a minority of the neuronal population of the mammalian striatum (Wilson and Groves, 1980). Thus, the modulation of $\mathrm{HVA} \mathrm{Ca}^{2+}$ currents recorded from medium-spiny cells may have a profound impact in the control of GABA release within the striatum. In the present study we have shown that agonists of mGluRs, at approximately the same doses that inhibited GABA-mediated potentials, reduced $\mathrm{HVA} \mathrm{Ca}^{2+}$ currents from these neurons.

A reduction of $\mathrm{HVA} \mathrm{Ca}^{2+}$ currents by mGluRs agonists have been previously reported in hippocampal (Lester and Jahr, 1991; Swartz and Bean, 1992) and cortical (Sayer et al., 1992) neurons. However, a main difference concerning the identification of the subtype of $\mathrm{HVA} \mathrm{Ca}^{2+}$ channels modulated by mGluRs arose from these studies. Whereas in hippocampal cells N-type channels were implicated in this modulatory action (Swartz and 

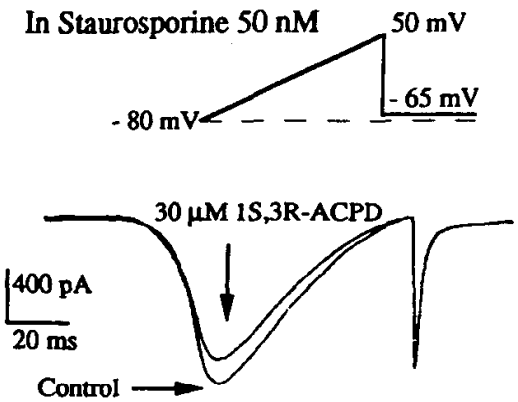

$30 \mu \mathrm{M} 15,3 R-A C P D$

$\square 30 \mu \mathrm{M}$ 1S,3R-ACPD in $50 \mathrm{nM}$ Staurosporine

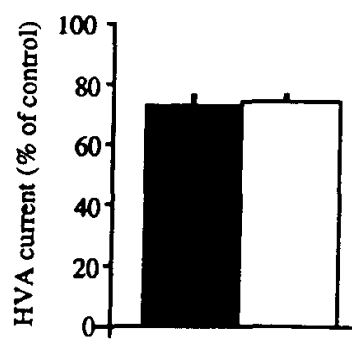

In Staurosporine $50 \mathrm{nM}$

$30 \mu \mathrm{M}$ 1S,3R-ACPD
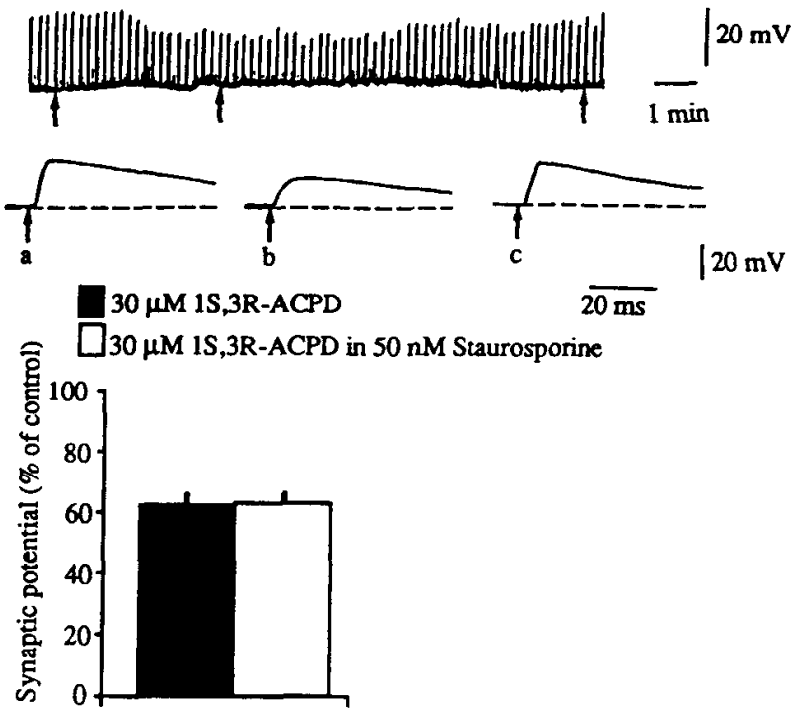

Figure 8. The mGluR-mediated modulation of $\mathrm{HVA} \mathrm{Ca}^{2+}$ channels and GABA potentials is not prevented by preincubation in staurosporine. Left, $1 S, 3 R$-ACPD at $30 \mu \mathrm{M}$ inhibited by about $19 \%$ the ramp-activated $\mathrm{Ba}^{2+}$ currents despite prolonged application (10 min) of $50 \mathrm{nM}$ staurosporine. The histogram below shows that no significant difference in the ACPD-mediated inhibition of HVA currents is detected between control ( $n=10$ ) and pretreated $(n=7)$ cells. Right, The chart record at low speed (upper trace) shows the membrane potential $(-85 \mathrm{mV})$ and the GABA-mediated potentials (upward deflections) of striatal cell recorded from a slice incubated in $50 \mathrm{~nm}$ staurosporine. In the lower traces synaptic potentials selected before $(a)$, during $(b)$, and after $(c)$ ACPD application are shown at higher sweep speed. The histogram below shows the efficacy of mGluRs agonist in reducing GABA potentials even in the presence of staurosporine $(n=10)$.

Bean, 1992), in cortical neurons L-type channels were involved in the effects of ACPD (Sayer et al., 1992). Our data suggest that the inhibitory effects of mGluRs on striatal HVA currents are sustained by the modulation of $\mathrm{N}$-type channels. In fact, $\omega$-conotoxin, but not nifedipine, occluded the mGluR-mediated inhibition of $\mathrm{HVA} \mathrm{Ca}^{2+}$ currents. In agreement with these evidences, in the present report we have also shown that $\omega$-conotoxin dramatically decreases GABA-mediated synaptic poten-

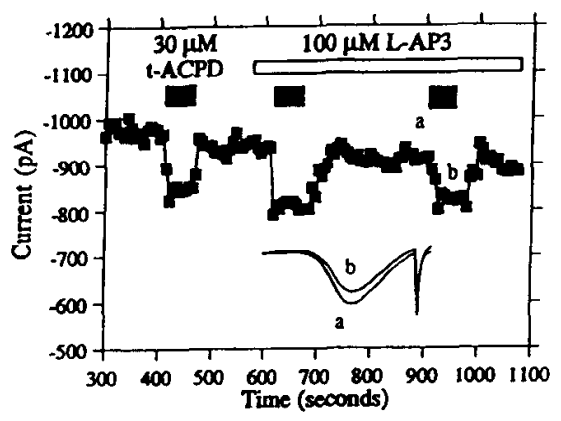

$30 \mu \mathrm{M}$ t-ACPD

$30 \mu \mathrm{M}$ t-ACPD in L-AP3

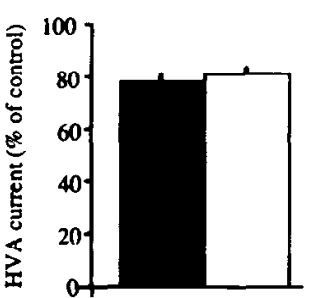

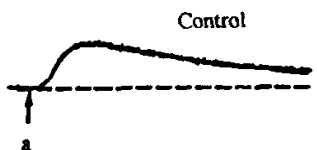

$30 \mu \mathrm{M} \mathrm{I}-\mathrm{ACPD}$
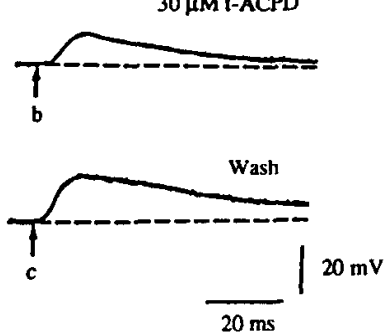

$30 \mu \mathrm{M}-\mathrm{ACPD}$

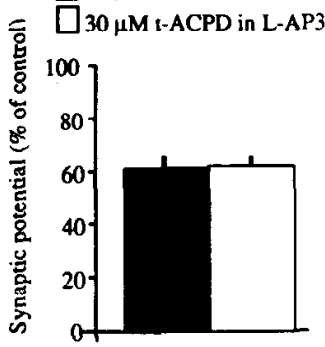

Figure 9. ACPD effects are not antagonized by L-AP3. Left, Time course of the effect of $t$-ACPD on HVA currents before and after L-AP3 $(100 \mu \mathrm{M})$ application is shown. The inset shows representative ramp-activated currents $(0.2$ $\mathrm{Hz}, 1 \mathrm{mV} / 1 \mathrm{msec})$. The histogram below compares the efficacy of the mGluR agonist in control and L-AP3-treated preparations $(n=7)$; no significant difference was observed. Right, $t$-ACPD responses on GABA-mediated potentials evoked in a striatal slice were not antagonized by $30 \mu \mathrm{M} \mathrm{L-AP} 3$ are shown. The histogram below shows the results obtained from similar experiments ( $n$ $=5$ ). 
tials and fully occludes the inhibitory effects of $\mathrm{mGluR}$ activation on these potentials. Yet, the percentage block of GABA-mediated DSPs by $\omega$-conotoxin is much greater than the percentage inhibition of HVA. This difference might be explained by two considerations: (1) the nonlinear relationship existing between presynaptic $\mathrm{Ca}^{2+}$ entry and transmitter release (Takahashi and Momiyama, 1993); (2) the possibility that $\omega$-conotoxin-sensitive channels are differentially distributed between somatic region and axon terminals. However, further biochemical and physiological studies should be performed in order to investigate the role of $\omega$-conotoxin-insensitive $\mathrm{Ca}^{2+}$ in the control of GABA release within the striatum (Pin and Bockaert, 1990). According with this consideration, in our recordings, a significant proportion of HVA currents are blocked neither by DHP antagonists nor by $\omega$-conotoxin. Interestingly, this finding has been previously reported for younger striatal cells (Hoehn et al., 1993). These observations suggest that either P-type channel (Hillman et al., 1991) or other yet unidentified types of $\mathrm{Ca}^{2+}$ channels contribute to HVA $\mathrm{Ca}^{2+}$ currents in the striatum. Recently, it has been shown that $\mathrm{P}$-type $\mathrm{Ca}^{2+}$ channels may play a role in the control of GABA synaptic potentials in different CNS structures (Takahashi and Momiyama, 1993; Toth et al., 1993). Nevertheless, our finding that the large part of the striatal GABAmediated synaptic potential is $\omega$-conotoxin sensitive seems to suggest that P-type channels do not play a major role in striatal GABA-mediated transmission.

\section{Possible postreceptor mechanisms underlying mGluR-mediated modulation of HVA channels}

In the presence of internal GTP- $\gamma-\mathrm{S}$, the HVA current suppression by mGluR agonists was irreversible, suggesting a G-protein involvement in the observed modulation. Furthermore, the speed and reversibility of ACPD action on HVA currents were similar to those of other transmitters that have been found to inhibit $\mathrm{Ca}^{2+}$ channels via G-protein-mediated processes (Brown and Birnbaumer, 1988; Lipscombe et al., 1989; Toselli et al., 1989). In CA3 pyramidal neurons, Swartz and Bean (1992) have previously described similar physiological and pharmacological characteristics of the mGluR-mediated action on HVA currents.

In most of our whole-cell recordings, high concentrations of the $\mathrm{Ca}^{2+}$ chelator, EGTA, were present in the internal dialyzing solution and $\mathrm{Ba}^{2+}$ replaced $\mathrm{Ca}^{2+}$ as charge carrier of $\mathrm{HVA}$ channels. Therefore, we can hypothesize that mobilization of internal $\mathrm{Ca}^{2+}$ is not a limiting step in the modulation of HVA currents by ACPD. Further evidence in favor of this hypothesis was the finding that the efficacy of the inhibitory effect of ACPD in the presence of external $\mathrm{Ca}^{2+}$ was similar to that observed in the presence of $\mathrm{Ba}^{2+}$. Differently from our observation, the mGluRmediated modulation in neocortical neurons (Sayer et al., 1992) was relatively slow and required the presence of $\mathrm{Ca}^{2+}$ in the external medium, suggesting differential transduction mechanisms between cortical and striatal neurons. It is interesting to stress that, in hippocampal neurons, the kinetics of ACPDmediated modulation of HVA currents were dependent upon $\mathrm{Ca}^{2+}$ buffering; only the increase in the steady state intracellular $\mathrm{Ca}^{2+}$ could in fact reveal a slow component of the inhibition, which presumably involved L-type channels (Sahara and Westbrook, 1993).

In this study, we have also shown that staurosporine, which is known to block protein kinase C (Hidaka and Kobayashi, 1992), does not alter either GABA-mediated synaptic potentials or HVA currents. Our findings, however, do not rule out other possible postreceptor mechanisms such as increase in cAMP accumulation (Winder and Conn, 1993) and inhibition of cAMP formation (Cartmell et al., 1992; Schoepp et al., 1992). Nevertheless, it should be stressed that both these effects have been shown to be blocked by L-AP3 (Schoepp and Johnson, 1992; Winder and Conn, 1992), which, at least at the concentration used in our experiments, did not significantly affect the mGluRmediated modulation of GABA-mediated potentials and HVA currents.

\section{Functional implications}

Our results show that L-AP3-insensitive mGluRs modulate $\omega$-conotoxin-sensitive HVA Ca ${ }^{2+}$ channels as well as GABAmediated potentials in the striatum. We propose that these two actions can be functionally linked. In fact, the inhibition of $\mathrm{Ca}^{2+}$ conductances, if also occurring at the axon terminals, may produce a decrease of the GABA release within the striatum. As previously described (Calabresi et al., 1992a; Lovinger et al., 1993), mGluRs mediate also a reduction of glutamate release from corticostriatal terminals.

In addition to these effects, we have also recently shown that activation of $\mathrm{mGluRs}$ may play a role in the generation of striatal I.TD. However, the mGluRs involved in this form of synaptic plasticity seem to be functionally and pharmacologically different from those involved in short-term modulation of transmitter release. In fact, L-AP3 blocks the long-term changes of synaptic transmission induced by tetanic stimulation of corticostriatal pathway but it does not alter the MGluR-mediated inhibition of glutamate and GABA release. All these findings taken together suggest a complex modulatory role of mGluRs in the physiology of the striatum.

It has been recently shown that the mGluR2 subtype is involved in the mGluR-mediated regulation of GABA-mediated synaptic potentials in olfactory bulb (Hayashi et al., 1993). It is possible that an $\mathrm{mGluR} 2 / \mathrm{mGluR} 3$ subgroup may also contribute to the effects we have observed in the present study. Further studies in order to address this issue are in progress in our laboratory.

\section{References}

Bargas J, Surmeier DJ, Kitai ST (1991) High- and low-voltage activated calcium currents are expressed by neurons cultured from embryonic rat neostriatum. Brain Res 541:70-74.

Bargas J, Howe A, Eberwine J, Carter-Russell H, Cao Y, Surmeier DJ (1994) Acutely isolated neostriatal neurons express four types of highvoltage-activated $\mathrm{Ca}^{2+}$ current. J Neurosci, in press.

Baskys A, Malenka RC (1991) Agonists at metabotropic glutamate receptors presynaptically inhibit EPSCs in neonatal rat hippocampus. J Physiol (Lond) 444:687-701.

Brown AM, Birnbaumer L (1988) Direct G protein gating of ion channels. Am J Physiol 254:H401-H410.

Calabresi P, Misgeld U, Dodt HU (1987) Intrinsic membrane properties of neostriatal neurons can account for their low level of spontaneous activity. Neuroscience 20:293-303.

Calabresi P, DeMurtas M, Mercuri NB, Bernardi G (1991) Involvement of GABA systems in the feedback regulation of glutamate- and GABA-mediated synaptic potential in rat neostriatum. J Physiol (Lond) 440:581-599.

Calabresi P, Mercuri NB, Bernardi G (1992a) Activation of quisqualate metabotropic receptors reduces glutamate and GABA-mediated synaptic potentials in the rat striatum. Neurosci Lett 139:4144.

Calabresi P, Maj R, Pisani A, Mercuri NB, Bernardi G (1992b) Longterm synaptic depression in the striatum: physiological and pharmacological characterization. J Neurosci 12:4224-4233. 
Calabresi P, Pisani A, Mercuri NB, Bernardi G (1993a) Heterogeneity of glutamatc metabotropic receptors in the striatum: electrophysiological evidences. Eur J Neurosci 5:1370-1377.

Calabresi P, Pisani A, Mercuri NB, Bernardi G (1993b) Lithium treatment blocks long-term synaptic depression in the striatum. Neuron 10:955-962.

Cartmell J, Kemp JA, Alexander SPH, Hill SJ, Kendall DA (1992) Inhibition of forskolin-stimulated cyclic AMP formation by 1-aminocyclopentane-trans-1,3-dicarboxylate in guinea pig cerebral cortical slices. J Neurochem 58:1964-1966.

Chang HT, Wilson CJ, Kitai ST (1982) A Golgi study of the rat neostriatal neurons. J Comp Neurol 208:107-126.

Desai MA, Conn JP (1991) Excitatory effects of ACPD receptor activation in the hippocampus are mediated by direct effects on pyramidal cells and blockade of synaptic transmission. J Neurophysiol 66:40-52.

Desai MA, Smith TS, Conn JP (1992) Multiple metabotropic glutamate receptors regulate hippocampal function. Synapse 12:206-213.

DiFiglia M, Pasik P, Pasik T (1976) A Golgi study of neuronal types in the neostriatum of monkeys. Brain Res 114:245-256.

Dunlap K, Holz GG, Rane SG (1987) G-proteins as regulators of ion channel function. Trends Neurosci 10:241-244.

Glaumm SR, Miller RJ (1992) Metabotropic glutamate receptors mediate excitatory transmission in the nucleus of the solitary tract. J Neurosci 12:2251-2258.

Hayashi Y, Momiyama A. Takahashi T, Ohishi H, Ogawa-Meguro R, Shigemoto R, Mizuno N, Nakanishi S (1993) Role of a metabotropic glutamate receptor in synaptic modulation in the accessory olfactory bulb. Nature 366:687-690.

Hidaka H, Kobayashi R (1992) Pharmacology of protein kinase in hibitors. Annu Rev Pharmacol Toxicol 32:377-397.

Hillman D, Chen S, Aung TT, Cherskey B, Sugimori M, Llinas RR (1991) Localization of P-type calcium channels in the central nervous system. Proc Natl Acad Sci USA 88:7076-7080.

Hoehn K, Watson TWJ, MacVicar BA (1993) Multiple types of calcium channels in acutely isolated rat neostriatal neurons. J Neurosci 13:1244-1257.

Irving AJ, Schofield G, Watkins JC, Sunter DC, Collingridge GL (1990) $1 S, 3 R$-ACPD stimulates and L-AP3 blocks Ca mobilization in rat cerebellar neurons. Eur J Pharmacol 186:363-365.

Jiang ZG, North RA (1991) Membrane properties and synaptic responses of two types of rat striatal neurons in vitro. J Physiol (Lond) 443:533-553.

Kitai ST, Preston RJ, Bishop GA, Kocsis JD (1979) Striatal projection neurons: morphological and electrophysiological studies. In: Advances in neurology, The extrapyramidal system and its disorders (Poirier LJ, ed), pp 45-51. New York: Raven.

Lester RAJ, Jahr CE (1990) Quisqualate receptor-mediated depression of calcium currents in hippocampal neurons. Neuron 4:741-749.

Linden DJ, Dickinson MH, Smeyne M, Connor JA (1991) A longterm depression of AMPA currents in cultured cerebellar Purkinje neurons. Neuron 7:81-89.

Lipscombe D, Kongsamut S, Tsien RW (1989) Alpha-adrenergic inhibition of sympathetic neurotransmitter release mediated by modulation of N-type calcium-channel gating. Nature 340:639-642.

Lovinger DM, Tyler E, Fidler S, Merritt A (1993) Properties of a presynaptic metabotropic glutamate receptors in rat neostriatal slices. J Neurophysiol 69:1236-1244.

Miller RJ (1991) Metabotropic excitatory amino acid receptors reveal their true colors. Trends Pharmacol Sci 12:365-367.

Misgeld U, Calabresi P, Dodt HU (1986) Muscarinic modulation of calcium-dependent plateau potentials in rat neostriatal neurons. Pfluegers Arch 407:482-487.

Mody I, Salter MW, McDonald JF (1989) Whole-cell voltage-clamp recordings in granule cells acutely dissociated from hippocampal slices from adult or aged rats. Neurosci Lett 96:70-75.

Nahorski SR, Ragan CI, Challiss RAJ (1991) Lithium and the phosphoinositide cycle: an example of uncompetitive inhibition and its pharmacological consequences. Trends Pharmacol Sci 12:297-303.

Nakanishi S (1992) Molecular diversity of glutamate receptors and implications for brain functions. Science 258:597-602.

Nowicky MC, Fox AP, Tsien RW (1985) Long-opening mode of gating of neuronal calcium channels and its promotion by the dihydropyridine calcium agonist Bay K 8644. Proc Natl Acad Sci USA 82:21782182.

Otani S, Ben-Ari Y (1991) Metabotropic receptor-mediated long-term potentiation in rat hippocampal slices. Eur J Pharmacol 205:325326.

Pin JP, Bockaert JW (1990) Conotoxin GVIA and dihydropyridines discriminate two types of calcium channels involved in GABA release from striatal neurons in culture. Eur J Pharmacol 188:81-84.

Sahara Y, Westbrook GL (1993) Modulation of calcium currents by a metabotropic glutamate receptor involves fast and slow kinetic components in cultured hippocampal neurons. J Neurosci 13:30413050 .

Sayer RJ, Schwindt PC, Crill WE (1992) Metabotropic receptor-mediated suppression of L-type calcium currents in acutely isolated neocortical neurons. J Neurophysiol 68:833-842.

Schoepp DD, Conn PJ (1993) Metabotropic glutamate receptors in brain functions. Trends Pharmacol Sci 14:13-20.

Schoepp DD, Johnson BG (1993) Pharmacology of metabotropic glutamate receptor inhibition of cyclic AMP formation in the adult rat hippocampus. Neurochem Int 22:277-283.

Schoepp DD, Bockaert J, Sladeczek F (1990) Pharmacological and functional characteristics of metabotropic excitatory amino acid receptors. Trends Pharmacol Sci 11:508-515.

Schoepp DD, Johnson BG, Monn JA (1992) Inhibition of cyclic AMP formation by a selective metabotropic glutamate receptor agonist. $\mathbf{J}$ Neurochem 58:1184-1186.

Somogyi P, Bolam JP, Smith AD (1981) Monosynaptic cortical input and local axon collaterals of identified striatonigral neurons. A light and electron microscopic study using the Golgi-peroxidase transportdegeneration procedure. J Comp Neurol 195:567-584.

Stanton PK, Chattarji S, Sejnowski T (1991) 2-Amino-3-phosphonopropionic acid, an inhibitor of glutamate-stimulated phosphoinositide turnover, blocks induction of homosynaptic long-term depression, but not potentiation, in rat hippocampus. Neurosci Lett 127: 61-66.

Surmeier DJ, Eberwine J, Wilson CJ, Cao Y, Stefani A, Kitai ST (1992) Dopamine receptor subtypes colocalize in rat striatonigral neurons. Proc Natl Acad Sci USA 89:10178-10182.

Swartz KJ, Bean BP (1992) Inhibition of calcium channels in rat CA3 pyramidal neurons by a metabotropic glutamate receptor. I Neurosci $12: 4358-4371$.

Takahashi T, Momiyama A (1993) Different types of calcium channels mediate central synaptic transmission. Nature 366:156-158.

Tanabe Y, Masu M, Ishii T, Shigemoto R, Nakanishi S (1992) A family of metabotropic glutamate receptors. Neuron 8:169-179.

Toselli M, Lang J, Costa T, Lux HD (1989) Direct modulation of voltage-dependent calcium channels by muscarinic activation of a pertussis toxin-sensitive G-protein in hippocampal neurons. Pfluegers Arch 415:255-261.

Toth PT, Bindokas VP, Bleakman D, Colmers WF, Miller RJ (1993) Mechanism of presynaptic inhibition by neuropeptide $Y$ at sympathetic nerve terminals. Nature 364:635-639.

Trautwein W, Kameyama M, Hescheler J, Hofman F (1986) Cardiaccalcium channels and their transmitter modulation. Fortschr Zool 33: 163-182.

Trombley PQ, Westbrook GL (1992) L-AP4 inhibits calcium channels and synaptic transmission via a G-protein-coupled glutamate receptor. J Neurosci 12:2043-2050.

Wilson CJ, Groves PM (1980) Fine structure and synaptic connections of the common spiny neuron of the rat neostriatum. A study employing intracellular injection of horseradish peroxidase. J Comp Neurol 194:599-615.

Winder DW, Conn PJ (1992) Activation of the metabotropic glutamate receptors in the hippocampus increases cyclic AMP accumulation. Neuroscience 59:375-378.

Winder DW, Conn PJ (1993) Activation of metabotropic glutamate receptors increases cAMP accumulation in hippocampus by potentiating responses to endogenous adenosine. J Neurosci 13:38-44.

Zheng F, Gallagher JP (1992) Metabotropic glutamate receptors are required for the induction of long-term potentiation. Neuron 9:163172. 